\title{
DETERMINATION OF ASPERGILLUS FUMIGATUS ALLERGEN 1 IN POULTRY FARMS USING THE ENZYME IMMUNOASSAY
}

\author{
Ljerka PRESTER ${ }^{1}$, Jelena MACAN ${ }^{1}$, Kristina MATKOVIĆ ${ }^{2}$, and Marija VUČEMILO² \\ Institute for Medical Research and Occupational Health ${ }^{1}$, Veterinary Faculty, University of Zagreb², \\ Zagreb, Croatia
}

Received in October 2009

Accepted in January 2010

\begin{abstract}
Poultry farms contain high levels of allergenic fungi, and Aspergillus spp. is the most common genus of moulds. Aspergillus fumigatus antigens are responsible for the development of several respiratory diseases including asthma. The aim of this study was to measure the mass fraction of Asp $\mathrm{f} 1$, a major allergen of Asperillus fumigatus in 37 indoor dust samples collected from four poultry farms in a rural area of the Zagreb County (Croatia) using the enzyme-linked immunosorbent assay. More than $62 \%$ of dust samples had detectable Asp f 1 levels (limit of detection $3.6 \mathrm{ng} \mathrm{g}^{-1}$ ). The overall mean Asp f 1 level was $17.9 \mathrm{ng} \mathrm{g}^{-1}$ [range (3.8 to 72.4) $\mathrm{ng} \mathrm{g}^{-1}$ ]. Satisfactory results were obtained for analytical within-run imprecision (6.7\%), between-run imprecision (10.5\%), and accuracy (91\% to $115 \%$ ). Microclimate parameters (air temperature, relative humidity, and velocity) were within the recommended ranges in all poultry farms. This study has shown that Asp f 1 settles on dust at poultry farms and that occupational exposure to this allergen deserves monitoring in livestock buildings.
\end{abstract}

KEY WORDS: Asp f 1, ELISA, farm workers, A. fumigatus, mould, mould allergen

Poultry farms contain high levels of microorganisms (bacteria, fungi, moulds) and microbial products (endotoxins, mycotoxins, glucans) during common, daily operations. In the recent years, exposure to allergenic moulds is of growing concern in various animal houses (swine, poultry, dairy). Aspergilli, particularly Aspergillus versicolor (A. versicolor) and Aspergillus fumigatus (A. fumigatus) dominate in indoor mould-contaminated environments (1) and were identified in livestock buildings, including poultry farms (2-4). The conidia of A. fumigatus are relatively small $(<3 \mu \mathrm{m}$ in diameter) and easily deposit in human or animal lung, causing several respiratory diseases (5-7). They may contribute to higher prevalence of chronic bronchitis, reduced lung function, airway inflammation, and toxic pneumonitis in poultry farm workers (8-10). In stabled horses, inhalation of mould antigens reflected in a significant lung dysfunction with recurrent airway obstruction (heaves) $(11,12)$.

Spores and hyphae of A. fumigatus contain numerous aeroallergens $(13,14)$. Asp f 1 (18-kDa protein) belongs to the ribotoxin family and is the major allergen of $A$. fumigatus $(15,16)$. Germination of A. fumigatus conidia increases the expression of Asp $\mathrm{f} 1$ allergen from spores and hyphae and the related inhalant hazard (17-19). Multiplication of moulds in poultry farms is influenced by atmospheric conditions, outdoor-indoor spore transport, environmental parameters, maintenance activity, and overall hygienic conditions $(20,21)$. Therefore, colonisation of $A$. fumigatus in reservoir dust can affect their allergen level considerably. However, there is not much information available on the Asp $\mathrm{f} 1$ allergen level 
in animal farming environments. In our recent study, settled dust was found to be a secondary source of exposure to Alternaria alternata allergen Alt a 1 in poultry farms (21).

Evaluating the role of mould allergens in occupational environments requires a reliable method for their detection. To date, analysis of mould exposure has not been standardised, and mould allergens have been less investigated. Indoor mould exposure is most frequently studied using both the microscopic (total spore count) and culture-based (cfu count) scoring methods for airborne or settled dust samples (22). However, mould allergens are released together with spores and hyphae from contaminated surfaces and these identification methods may underestimate actual exposure. Furthermore, fungal allergens are capable of causing health effects by means of hyphal fragments and not just by inhalation of intact spores. This is why exposure assessment should include methods detecting mould allergens or their fragments (23). There are several such methods, including halogen immunoassays and the enzyme-linked immunosorbent assay (ELISA), using monoclonal (mAbs) or polyclonal antibodies (pAbs) (24). The ELISA assay has established itself as a reference standard for indoor allergen exposure assessment in house dust (25). However, household application of this assay for fungal allergen determinations has its limitations, as Asp f 1 and Alt a 1 allergens are rare in residential dust (26). In contrast, our earlier study has shown widespread distribution of dust-borne Alt a 1 in poultry farms in a rural area of the Zagreb County, Croatia (21). To our knowledge, no data have been published so far on Asp f 1 content in various agricultural environments. Therefore, the aim of this pilot study was to determine Asp f 1 levels in settled dust samples collected from four poultry farms in a rural area of the Zagreb County (Croatia).

\section{MATERIALS AND METHODS}

\section{Poultry farms}

Four poultry farms were included in this study. At poultry farms 1 and 3, laying hens for eggs production were bred in conventional cages. Each dwelling housed about 10,000 laying hens. The buildings had no windows, but used forced ventilation, and the microclimate was regulated automatically. At poultry farm 2, laying hens (about 1000) and roosters (parent flock) were bred in cage-free conditions. Microclimate was regulated manually. Poultry farm 4, accommodating 22,000 broilers and laying hens, was a prefab building fitted on concrete foundations, the floor had a $10 \mathrm{~cm}$ deep sawdust litter layer, and used forced ventilation. At each poultry farm, air temperature, relative humidity, and airflow were measured at five locations using a Testo 400 device (Testo Inc. Lenzkirch, Germany).

\section{Dust collection and extraction}

We found no visible signs of mould contamination at the studied locations. Thirty-seven bulk dust samples were collected from the four poultry farms in February-April 2007 as a part of a research project evaluating fungal and mite exposure in poultry farms.

All dust samples were collected from the floors of different locations between 7 and 9 a. m. Samples were placed in sterile plastic bags and stored at $-20{ }^{\circ} \mathrm{C}$ until extraction. Before extraction, large debris was removed from the dust samples using a $300 \mu \mathrm{m}$ sieve. 100-mg aliquots of fine dust were extracted with $2 \mathrm{~mL}$ of phosphate-buffer saline containing $0.05 \%$ Tween (Merck) (PBS-T) as described elsewhere (27). The supernatants were stored at $-20{ }^{\circ} \mathrm{C}$ until analysis.

\section{ELISA for Asp f 1}

The concentration of Asp $\mathrm{f} 1$ was determined using a commercial ELISA kit (Indoor Biotechnologies Ltd, Cardiff, UK) as described elsewhere (18). Mouse antiAsp f 1 monoclonal Ab (clone 4A6, isotype IgG1) (Product code: MA-4A6; lot no. 2764) was used as capture antibody, and rabbit polyclonal anti-Asp f 1 (Product code: PA-AF1; lot no. 2765) as detecting antibody. This antiserum contains IgG to Asp f 1 and antibodies to other Aspergillus allergens. Purified natural Asp f 1 extract (400 ng Asp f 1 per $1 \mathrm{~mL}$ ) was used as a reference standard (Product code: ST-AF1; lot no. 2521). By doubling the dilutions of this standard (from $100 \mathrm{ng} \mathrm{mL}^{-1}$ to $0.03 \mathrm{ng} \mathrm{mL}^{-1}$ ) we formed a standard curve. Standards and dust extracts were diluted in PBS-T containing $1 \%$ bovine serum albumine (BSA)(Sigma; lot no. 017K0775) (PBS-TBSA).

Ninety-six-well Maxisorps plates (Nunc, Roskilde, Denmark) were coated with $100 \mu \mathrm{L}$ of mouse $\mathrm{mAb}\left(10 \mu \mathrm{L}\right.$ per $10 \mathrm{~mL}$ of $50 \mathrm{mmol} \mathrm{L}^{-1}$ carbonatebicarbonate buffer, $\mathrm{pH}$ 9.6) at room temperature 
over night. After washing with PBS-T three times, the plates were blocked with PBS-T-BSA $(300 \mu \mathrm{L}$ per well) for $30 \mathrm{~min}$ and washed. The plates were then incubated with dust extracts diluted two to eight times and serially diluted standards for $1 \mathrm{~h}$. After three washing steps, the plates were incubated $(100 \mu \mathrm{L}$ per well) with rabbit anti-A. fumigatus $\mathrm{pAb}(10 \mu \mathrm{L}$ per $10 \mathrm{~mL}$ of PBS-T-BSA) for $1 \mathrm{~h}$. Then the wells were washed and bound Asp f 1 was treated $(100 \mu \mathrm{L}$ per well) with peroxidase-conjugated goat anti-rabbit $\operatorname{IgG}$ as detecting antibody $(10 \mu \mathrm{L}$ per $10 \mathrm{~mL}$ of PBS-TBSA, Cat. \# 111-036-046) (Jackson Immunoresearch Laboratories, Inc., West Grove, PA). After additional 1-hour incubation, the plates were aspirated again and extensively washed in PBS-T buffer four times. The assay was performed by adding a substrate solution (100 $\mu \mathrm{L}$ per well) of TMB (Tetramethylbenzidine) and peroxide (Adaltis, Italy), and the reaction was stopped using sulphuric acid $\left(1.0 \mathrm{~mol} \mathrm{~L}^{-1}\right)$. Optical density was determined at $450 \mathrm{~nm}$ on a PersonalLab microplate reader (IASON, Graz, Austria). The analyses were carried out in triplicate. Results for dust extracts were calculated from blank-corrected absorbance values using linear regression analysis and are expressed as ng of Asp $\mathrm{f} 1$ per $\mathrm{g}$ of sieved dust ( $\left.\mathrm{ng} \mathrm{g}^{-1}\right)$.

\section{Analytical validation}

Intra-assay imprecision was determined as coefficient of variation (\%) from daily replicate analyses $(n=20)$ of one dust extract containing low Asp $\mathrm{f} 1$ level. Inter-assay imprecision was determined by repeated determination of the same control extract over five days (four repetitions a day). Accuracy was evaluated by calculating recovery (\%) of Asp f 1 measurements using repeated analyses of dust extract spiked with diluted standard $\left(0.12 \mathrm{ng} \mathrm{mL}^{-1}, \mathrm{n}=5\right)$. Limit of detection (LOD) was calculated by measuring the absorbance of 10 replicates of blank +3 standard deviations.

\section{Statistics}

All data were analysed using the statistical analysis package Statistica for Windows release 5.5 (StatSoft Inc., USA). The results are presented as median, range (minimum-maximum), and the percentile $\left(25^{\text {th }}, 75^{\text {th }}\right.$, $90^{\text {th }}$ ) as a measure of variation (interquartile range). Mann-Whitney test was used to test the significance of the difference between Asp $f 1$ levels in poultry farms. All samples with concentrations below limit of detection were assigned a value of two-thirds of the detection limit. The level of significance $(\mathrm{P})$ was set at 0.05 .

Because there are no established standard limits for mould allergens, Asp f 1 levels were divided into four groups: undetectable ( $<\mathrm{LOD})$, very low (LOD to $25^{\text {th }}$ percentile), low-to-moderate $\left(25^{\text {th }}\right.$ to $90^{\text {th }}$ percentile), and elevated $\left(>90^{\text {th }}\right.$ percentile $)$.

\section{RESULTS AND DISCUSSION}

Our results show that $62 \%$ of dust samples collected at poultry farms had a detectable Asp f 1 level (Figure 1). Dust-borne Asp f 1 level was low (median=17.9 $\mathrm{ng} \mathrm{g}^{-1}$ fine dust, $\mathrm{n}=23$ ), but varied (up to 20 times) between the farms. At poultry farm 3 it was significantly lower $(\mathrm{P}<0.05)$ than at poultry farms 1 and 2. Only at farm 4, Asp f 1 was below the detection limit in all dust samples (Table 1). High Asp f 1 ( $>31.7 \mathrm{ng} \mathrm{g}^{-1}$ or $\left.>90^{\text {th }}\right)$ levels were found in only three dust samples (Figure 1). To our knowledge, there is no information about Asp $\mathrm{f} 1$ levels at poultry farms published in literature.

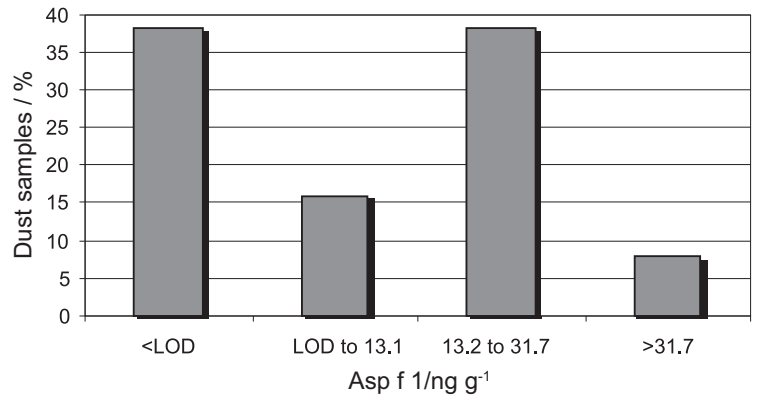

Figure 1 Percentage (\%) of dust samples ( $n=37)$ from poultry farms by Asp $f 1$ level $\left(\mathrm{ng} \mathrm{g}^{-1}\right)$ : below the level of detection $\left(<L O D ; 3.6 \mathrm{ng} \mathrm{g}^{-1}\right)$, LOD to $25^{\text {th }}$ percentile (very low), $25^{\text {th }}$ to $90^{\text {th }}$ percentile (low-to-moderate), and $>90^{\text {th }}$ percentile (high).

Outdoor measurements of airborne Asp f 1 are scarce. Aspergillus is less common outdoors in any season and is considered the major indoor mould. In this study, we took samples from poultry farms in the early spring when outdoor airborne Aspergillus spores are extremely low (up to $4 \mathrm{cfu} \mathrm{m}^{-3}$ ) in this geographic area (28) and so is the release of Asp $\mathrm{f} 1$ from germinating mycelia. Although we have not scored A. fumigatus spores in indoor dust samples, our results suggest that the majority of dust-borne Asp $\mathrm{f} 1$ in poultry farms originate from indoor A. fumigatus multiplication, rather than from outdoor-to-indoor 
Table 1 The Asp $f 1$ median mass fraction (ng $g^{-1}$ fine dust), percentile $\left(25^{\text {th }}\right.$ to $\left.90^{\text {th }}\right)$, and ranges (min-max) in floor dust samples $(n=37)$ collected at four poultry farms near Zagreb

\begin{tabular}{|c|c|c|c|c|c|c|c|c|}
\hline \multirow{2}{*}{ Poultry farm } & \multirow{2}{*}{$\mathrm{n}$} & \multirow{2}{*}{ N (\%) } & \multicolumn{6}{|c|}{$\operatorname{Asp}$ f $1 / \operatorname{ng~g}^{-1}$} \\
\hline & & & $\min$ & $25^{\text {th }}$ & Median & $75^{\text {th }}$ & $90^{\text {th }}$ & $\max$ \\
\hline Farm 1 & 17 & $15(88)$ & 4.3 & 13.8 & $19.7 * *$ & 25.2 & 31 & 72.4 \\
\hline Farm 2 & 5 & $4(80)$ & 13.1 & 16.7 & $21^{* *}$ & 35 & 54.6 & 67.7 \\
\hline Farm 3 & 7 & $4(57)$ & 3.8 & 4.1 & $11^{*}$ & 19 & 21.2 & 22.8 \\
\hline Farm 4 & 8 & $0(0)$ & - & - & - & - & - & - \\
\hline
\end{tabular}

$n$-number of samples, $N$-number of positive samples

${ }^{*}(P<0.05),{ }^{* *}(P>0.05)$

Table 2 Microclimate parameters at the four poultry farms near Zagreb during sampling (ranges of means, $n=5$ )

\begin{tabular}{lcccc}
\hline Microclimate parameters & Farm 1 & Farm 2 & Farm 3 & Farm 4 \\
\hline Air temperature $/{ }^{\circ} \mathrm{C}$ & 15 to 19 & 13 to 17 & 22 to 27 & 15 to 21 \\
Relative humidity $/ \%$ & 60 to 72 & 58 to 67 & 49 to 70 & 60 to 69 \\
Airflow velocity $/ \mathrm{m} \mathrm{s}^{-1}$ & 0.14 to 0.67 & 0.15 to 0.53 & 0.07 to 0.1 & 0.17 to 0.31 \\
\hline
\end{tabular}

spore transport. These results are in accordance with Chew et al. (29), who have found that fungal spores can grow and produce new spores in indoor settled dust. Therefore, settled dust can be a secondary source of exposure to Asp f 1 allergen in poultry farms. In addition, indoor dust can be a source of nutrients for aspergilli, which can partly explain their colonisation on moist indoor surfaces (30). Several studies found that most Aspergilli grow optimally at temperatures between $22{ }^{\circ} \mathrm{C}$ and $26^{\circ} \mathrm{C}$ and that humidity increases the proliferation of dust mites and moulds $(20,31)$. Therefore, control of microclimate parameters (temperature, relative humidity, and air velocity) in various animal confinement buildings is extremely important for animal and human health. Furthermore, these microclimate parameters are the greatly affect bioaerosol settling, including mould allergens (32). The recommended temperature is from $15{ }^{\circ} \mathrm{C}$ to $20^{\circ} \mathrm{C}$ for laying hens and from $18{ }^{\circ} \mathrm{C}$ to $20^{\circ} \mathrm{C}$ for broilers; relative humidity from $60 \%$ to $70 \%$, and airflow rate from $0.2 \mathrm{~m} \mathrm{~s}^{-1}$ to $0.5 \mathrm{~m} \mathrm{~s}^{-1}$ (33, 34). Microclimate parameters in our study were within the recommended ranges in all poultry farms (Table 2). Other factors, such as maintenance (feeding, manure removal), animal population density, routine cleaning activities, and hygienic conditions $(20,35)$ could have affected the dust-borne Asp $\mathrm{f} 1$ levels at poultry farms 1-3 (Table 1). Other plausible factors are farm construction and availability of a substrate on which moulds can grow (36). Identification of indoor Asp f 1 requires urgent risk management due to potentially pathogenic allergic and toxic effects on animals and workers (37). Mould allergens should primarily be eliminated with major allergen reservoirs such as settled dust. The growth of $A$. fumigatus (including Asp f 1) can be reduced using commercially available products (38). Extensive literature reported that longterm exposure to even small doses of living or dead fungal propagules containing fungal allergens may modulate the immune response in occupants with normal immune status $(6,39)$.

Unlike poultry farms of the Zagreb County, none of the 30 urban households in the city of Zagreb, studied within our research project which includes this study, showed no detectable Asp f 1 (data not presented), which corroborates the finding of Sporik et al. (18) and Ryan et al. (40).

In our recent study, we estimated the levels of mould A. alternata (Alt a 1) allergen (range from $0.1 \mu \mathrm{g} \mathrm{g}^{-1}$ to $14 \mu \mathrm{g} \mathrm{g}^{-1}$ ) at poultry farms (21). Compared with Alt a 1, median Asp $f 1$ mass fraction in dust samples from poultry farms was 21 times lower. It is generally accepted that settled dust is the best proxy for long-term exposure to allergens at home and work $(29,41)$. Dust sampling is also used to determine the effectiveness of remediation of contaminated indoor surfaces (42). Furthermore, quantitative measurements of mite and pet allergens in settled dust have provided data about the relationship between allergen exposure and sensitisation (43). However, currently there are no standard limits for acceptable mould allergen levels in dust samples. Recently, Salo et al. (44) proposed a 
cut-off point of $7 \mu \mathrm{g} \mathrm{g}^{-1}$ for $A$. alternata antigens in household dust.

To our knowledge, the application of ELISA in determining Asp f 1 has not been validated for agricultural studies. The results of this study show that, with its limit of detection of $3.6 \mathrm{ng} \mathrm{g}^{-1}$, capture ELISA is a rapid and highly sensitive method for determining dust-borne Asp f 1 . This LOD is comparable to $5 \mathrm{ng} \mathrm{g}^{-1}$ in a study by Ryen et al. (40) and is lower than the LOD $0.12 \mu \mathrm{g} \mathrm{g}^{-1}$ for Alt al (21). Intra- and inter-assay imprecision for Asp f 1 were $6.7 \%$ and 10.5\%, respectively, and the accuracy was $91 \%$ to $115 \%$, which is completely satisfactory.

Fungi make numerous, common antigenic proteins, which can influence the specificity of the method. Asp f 1 is a species-specific allergen (17). However, the cross-reactivity with related proteins from phylogenetically distant species could not be excluded (45). Our results should be confirmed in other poultry farms in various geographic locations. Furthermore, as single determinations of mould allergens (similar to those for mite allergens) give limited information, repeated measurements are recommended.

In addition to allergens, poultry farms are also sources of endotoxin-rich bioaerosols $(20,46)$. Bacterial endotoxins may act synergistically with Aspergilus fumigatus antigens and lead to pulmonary disease of horses (heaves), similar to human occupational asthma in workers chronically exposed to organic dust in animal housing facilities (poultry, swine, dairy) (47). Finally, Aspergillus spp. are known to produce mycotoxins, and most of the cases of mycotoxin exposure have been described among farm workers and persons processing mouldy materials (37). Therefore, occupational exposure to $A$. fumigatus in poultry farms deserves monitoring. The contribution of airborne Asp $\mathrm{f} 1$ to total mould exposure in poultry farms should be further characterised.

\section{CONCLUSIONS}

Even though there are several limitations to this study, including the small sample size, inconsistency between the number of samples collected from each farms, and different hygienic conditions between the farms, this pilot study has merits of its own. It has shown that Asp $\mathrm{f} 1$ settles on dust at poultry farms if hygienic conditions are not satisfactory. Reservoir dust may become a hazardous secondary source of exposure to Aspergillus spp., for both worker and animal health. It has also shown that capture ELISA is a suitable assay for quantifying and monitoring dust-borne Asp $\mathrm{f} 1$ and for assessing exposure to $A$. fumigatus at poultry farms. Considering the significant seasonal variation in indoor fungal levels, longitudinal surveys of air and dust samples could give an even clearer insight into mould allergen exposure in this environment.

\section{Acknowledgement}

This study was supported by the Ministry of Science, Education and Sports of the Republic of Croatia (Grand No 022-0222411-2410). The authors report no conflicts of interest. The authors alone are responsible for the content and writing the paper.

\section{REFERENCES}

1. Benndorf D, Müller A, Bock K, Manuwald O, Herbarth O, von Bergen M. Identification of spore allergens from the indoor mould Aspergillus versicolor. Allergy 2008;63:45460.

2. Clark S, Rylander R, Larsson L. Airborne bacteria, endotoxin and fungi in dust in poultry and swine confinement buildings. Am Ind Hyg Assoc J 1983;44:537-41.

3. Hartung J. Emissionen luftgetragener Stoffe aus Nutztierställen [Emissions of airborne substances from stalls of domestic animals, in German]. Pneumologie 1992;46:196-202.

4. Jo WK, Kang JH. Exposure levels of airborne bacteria and fungi in Korean swine and poultry sheds. Arch Environ Occup Health 2005;60:140-6.

5. Institute of Medicine (IOM). Damp Indoor Spaces and Health. Washington (DC): The National Academies Press; 2004.

6. Górny RL, Reponen T, Willeke K, Schmechel D, Robine E, Boissier M, Grinshpun A. Fungal fragments as indoor air biocontaminants. Appl Environ Microbiol 2002;68:352231 .

7. Green BJ, Tovey ER, Sercombe JK, Blachere FM, Beezhold DH, Schmechel D. Airborne fungal fragments and allergenicity. Med Mycol 2006;44(Suppl 1):S245-55.

8. Radon K, Danuser B, Iversen M, Jörres R, Monso E, Opravil U, Weber C, Donham KJ, Nowak D. Respiratory symptoms in European animal farmers. Eur Respir J 2001;17:747-54.

9. Omland Ǿ. Exposure and respiratory health in farming in temperate zones - a review of the literature. Ann Agric Environ Med 2002;9:119-36.

10. Rylander R, Carvalheiro MF. Airways inflammation among workers in poultry houses. Int Arch Occup Environ Health 2006;79:487-90.

11. Derksen FJ, Robinson N, Scott JS, Stick JA. Aerosolised Micropolyspora faeni antigen as a cause of pulmonary dysfunction in ponies with recurrent airway obstruction (heaves). Am J Vet Res 1988;49:933-8.

12. McGorum BC, Dixon P M, Halliwell RE. Responses of horses affected with chronic obstructive pulmonary disease to inhalation challenges with mould antigens. Equine Vet J $1993 ; 25: 261-7$ 
13. Latgé JP. Aspergillus fumigatus and Aspergillosis. Clin Microbiol Rev 1999;2:310-50.

14. Kurup VP, Banerjee B. Fungal allergens and peptide epitopes. Peptides 2000;21:589-99.

15. Arruda LK, Platts-Mills TAE, Fox JW, Chapman MD. Aspergillus fumigatus allergen I, a major IgE-binding protein, is a member of the mitogillin family of cytotoxins. J Exp Med 1990;172:1529-32.

16. Latgé JP, Moutaouakil M, Debeaupuis JP, Bouchara JP, Haynes K, Prévost MC. The 18-kilodalton antigen secreted by Aspergillus fumigatus. Infect Immun 1991;59:2586-94.

17. Arruda LK, Mann BJ, Chapman MD. Selective expression of a major allergen and cytotoxin, Asp f 1, in Aspergillus fumigatus. Implications for the immunopathogenesis of Aspergillus related diseases. J Immunol 1992;149:3354-9.

18. Sporik RB, Arruda LK, Woodfolk J, Chapman MD, PlattsMills TAE. Environmental exposure to Aspergillus fumigatus allergen (Asp f I). Clin Exp Allergy 1993;23:326-31.

19. Green BJ, Mitakakis TZ, Tovey ER. Allergen detection from 11 fungal species before and after germination. J Allergy Clin Immunol 2003;111:285-9.

20. Vučemilo M, Matković K, Vinković B, Macan J, Varnai VM, Prester Lj, Granić K, Orct T. Effect of microclimate on the airborne dust and endotoxin concentration in a broiler house Czeh J Anim Sci 2008;53:83-9.

21. Prester Lj, Macan J. Determination of Alt a 1 (Alternaria alternata) in poultry farms and a sawmill using ELISA Medical Mycol 2010;48:298-302. DOI: 10.1080/13693780 9031.15402.

22. Portnoy JM, Barnes CS, Kennedy K. Sampling for indoor fungi. J Allergy Clin Immunol 2004;113:189-98.

23. Green BJ, Schmechel D, Sercombe JK, Tovey ER. Enumeration and detection of aerosolized Aspergillus fumigatus and Penicillium chrysogenum conidia and hyphae using a novel double immunostaining technique. J Immunol Methods 2005;307:127-34.

24. Dillon KH, Boling DK, Miller JD. Comparison of detection methods for Aspergillus fumigatus in environmental air samples in an occupational environment. J Occup Environ Hyg 2007;4:509-13.

25. Chapman MD, Tsay A, Vailes LD. Home allergen monitoring and control-improving clinical practice and patient benefits. Allergy 2001;56:604-10.

26. Vailes L, Sridhara S, Cromwell O, Weber B, Breitenbach M, Chapman M. Quantitation of the major fungal allergens, Alt a 1 and Asp f 1, in commercial allergenic products. J Allergy Clin Immunol 2001;107:641-6.

27. Prester Lj, Brčić Karačonji I, Macan J. Determination of mite allergens in house dust using the enzyme immunoassay. Arh Hig Rada Toksikol 2007;58:413-9.

28. Šegvić Klarić M, Pepeljnjak S. A year-round aeromycological study in Zagreb area, Croatia. Ann Agric Environ Med 2006;13:55-64.

29. Chew GL, Rogers C, Burge HA, Muilenberg ML, Gold DR. Dustborne and airborne fungal propagules represent a different spectrum of fungi with differing relations to home characteristics. Allergy 2003;58:13-20.

30. Pasanen P, Korpi A, Kalliokoski P, Pasanen AL. Growth and volatile metabolite production of Aspergillus versicolor in house dust. Environ Int 1997;23:425-32.

31. Peat JK, Dickerson J, Li J. Effects of damp and mould in the home on respiratory health: a review of the literature. Allergy $1998 ; 53: 120-8$
32. Mohr AJ. Microorganisms fate and transport. In: Hurst CJ, Crawford RL, Knudsen G, McInerney M, Stetzenbach LD, editors. Manual of environmental microbiology. Washington (DC): ASM Press; 2002. p. 827-38.

33. Harry EG. Air pollution in farm buildings and methods of control: a review. Avian Pathol 1978;7:441-54.

34. Ellen HH, Bottcher RW, von Wachenfelt E, Takai H. Dust levels and control methods in poultry houses. J Agric Safety Health 2000;6:275-82.

35. Matković K, Vučemilo M, Vinković B, Šeol B, Pavičić Ž, Tofant A. Effect of microclimate on bacterial count and airborne emission from dairy barns on the environment. Ann Agric Environ Med 2006;13:349-54.

36. Dharmage S, Bailey M, Raven J, Abeyawickrama K, Cao D, Guest D, Rolland J, Forbes A, Thien F, Abramson M, Walters EH. Mouldy houses influence symptoms of asthma among atopic individuals. Clin Exp Allergy 2002;32:714-20.

37. Fischer G, Dott W. Relevance of airborne fungi and their secondary metabolites for environmental, occupational and indoor hygiene. Arch Microbiol 2003;179:75-82.

38. Martyny JW, Harbeck RJ, Pacheco K, Barker EA, Sills M, Silveira L, Arbuckle S, Newman L. Aerosolized sodium hypochlorite inhibits viability and allergenicity of mold on building materials. J Allergy Clin Immunol 2005;116:6305.

39. Lang L. Danger in the dust. Environ Health Perspect 1996;104:26-30.

40. Ryan TJ, Whitehead LW, Connor TH, Burau KD. Survey of the Asp $\mathrm{f} 1$ allergen in office environments. Appl Occup Environ Hyg 2001;16:679-84.

41. Jacob B, Ritz B, Gehring U, Koch A, Bischof W, Wichmann HE, Heinrich J. Indoor exposure to mold and allergic sensitization. Environ Health Perspect 2002;110:647-53.

42. Andersson MA, Nikulin M, Koljalg U, Andersson MC, Rainey F, Reijula K, Hintikka E, Salkinoja-Salonen M. Bacteria, molds, and toxins in water-damaged building materials. Appl Environ Microbiol 1997;63:387-93.

43. Dreborg S. Mite allergens. Collection, determination, expression of results and risk levels for sensitization and symptom induction. Allergy 1998;53(48 Suppl):88-91.

44. Salo PM, Arbes SJ, Crockett PW, Thorne PS, Cohn RD, Zeldin DC. Exposure to multiple indoor allergens in US homes and its relationship to asthma. J Allergy Clin Immunol 2008;121:678-84.

45. Schmechel D, Simpson JP, Beezhold D, Lewis DM. The development of species-specific immunodiagnostics for Stachybotrys chartarum: The role of cross-reactivity. J Immunol Methods 2006;309:150-9.

46. Seedorf J, Hartung J, Schröder M, Linkert KH, Phillips VR, Holden MR, Sneath RW, Short JL, White RP, Pedersen S, Tatai H, Johnsen JO, Metz JHH, Groot Koerkamp PWG, Uenk GH, Wathes CM. Concentrations and emissions of airborne endotoxins and microorganisms in livestock buildings in Northern Europe. J Agric Engin Res 1998;70:97107.

47. Pirie RS, Dixon PM, McGorum BC. Endotoxin contamination contributes to the pulmonary inflammatory and functional response to Aspergillus fumigatus extract inhalation in heaves horses. Clin Exp Allergy 2003;33:1289-96. 


\section{Sažetak \\ ODREĐIVANJE ALERGENA Asp f 1 (ASPERGILLUS FUMIGATUS) U PERADARNIKU ENZIM- IMUNOKEMIJSKOM METODOM}

Peradarnici sadržavaju veliku koncentraciju alergenih plijesni, a rod Aspergillus najčešće je zastupljen. Antigeni soja Aspergillus fumigatus odgovorni su za nastanak nekoliko respiratornih bolesti uključujući astmu. Cilj ovoga rada bio je odrediti masenu frakciju Asp f 1, glavnog alergena soja Asperillus fumigatus u 37 uzoraka prašine uzorkovanih u četiri peradarnika sa šireg područja Zagrebačke županije rabeći enzimimunokemijsku metodu. Više od 62 \% uzoraka prašine u tri peradarnika imalo je mjerljivu koncentraciju Asp f 1 (granica detekcije $\left.=3.6 \mathrm{ng} \mathrm{g}^{-1}\right)$. Ukupni srednji maseni udio Asp f 1 iznosio je $17.9 \mathrm{ng} \mathrm{g}^{-1}\left(\mathrm{raspon}_{\mathrm{od}}\right.$ $3.8 \mathrm{ng} \mathrm{g}^{-1}$ do $\left.72.4 \mathrm{ng} \mathrm{g}^{-1}\right)$. Dobiveni su zadovoljavajući rezultati za analitičku nepreciznost u seriji (6.7 \%), nepreciznost iz dana $u$ dan $(10.5 \%)$ i točnost $(91 \%$ do $115 \%)$. Mikroklimatski parametri (temperatura zraka, relativna vlaga i protok zraka) u svim peradarnicima bili su u okviru preporučenih vrijednosti. Rezultati ovoga rada pokazuju da Asp f 1 sedimentira na prašinu u peradarnicima te da profesionalnu izloženost tom alergenu treba pratiti u jedinicama za uzgoj stoke.

KLJUČNE RIJEČI: alergeni plijesni, Asp f 1, A. fumigatus, ELISA, plijesni, radnici na peradarskoj farmi

\section{CORRESPONDING AUTHOR:}

\section{Ljerka Prester}

Institute for Medical Research and Occupational Health P.O.Box 291, HR-10001 Zagreb, Croatia

E-mail:prester@imi.hr 